Charles M. Rush

Texas Agriculture Experiment Station, Amarillo

Jeffrey M. Stein

Plant Science Department, South Dakota State University, Brookings

Robert L. Bowden

USDA-ARS, Manhattan, KS
Robert Riemenschneider

USDA-FAS, Washington, D.C.

Theodore Boratynski

USDA-APHIS-PPQ, Phoenix, AZ

Matthew H. Royer

USDA-APHIS-PPQ, Riverdale, MD

\title{
Status of Karnal Bunt of Wheat in the United States 1996 to 2004
}

Karnal bunt $(\mathrm{Kb})$ of wheat was first identified in the United States in 1996, and its original and subsequent detections set off a cascade of events and activities that impact the U.S. wheat industry to this day. The USDA and state departments of agriculture established various programs to limit the spread of $\mathrm{Kb}$, and surveys were initiated to document growing regions where $\mathrm{Kb}$ did not occur. Federal regulatory agencies, state departments of agriculture, land grant universities, and state and national commodity organizations offered discussion sessions and workshops to educate those affected by Karnal bunt. A variety of research and extension programs were initiated to deal with the disease, and a flurry of popular, technical, and scientific articles was written. Since that time, although $\mathrm{Kb}$ is still an issue for U.S. wheat producers and exporters, the uproar that originally accompanied detection of the disease has subsided and new rules have been issued that allow producers more flexibility in dealing with the disease. In large part, these rule changes resulted from growing evidence that Tilletia indica is a nonaggressive pathogen that does not warrant its current status as a zero tolerance quarantine organism. Unfortunately, quarantine regulations are often slow to change, so $\mathrm{Kb}$ still has potential to disrupt the wheat export trade. The purpose of this report is to provide a chronological overview of the political, regulatory, and scientific activities since the discovery of $\mathrm{Kb}$ in the United States in 1996, and an update

Corresponding author: Charles M. Rush E-mail: CBKLRUSH@aol.com

\section{DOI: 10.1094/PD-89-0212}

This article is in the public domain and not copyrightable. It may be freely reprinted with customary crediting of the source. The American Phytopathological Society, 2005. on the progress of those programs and activities.

\section{A Brief Review of the Pathogen and Disease}

Karnal bunt, caused by the fungal pathogen Tilletia indica Mitra, is a disease of bread wheat (Triticum aestivum), durum wheat ( $T$. durum), and triticale (wheat $\times$ rye hybrid) $(25,56)$. The fact that $T$. indica seldom causes significant yield losses is partially due to its unusual life cycle and its extreme dependence on specific environmental conditions for disease development $(3,8,28)$. Teliospores are the survival propagules for $T$. indica $(34,61)$ (Fig. 1). They survive in the soil, and when exposed to high moisture $(22,53)$ and an optimum temperature range of 20 to $25^{\circ} \mathrm{C}(20,65)$, germinate to give rise to primary sporidia $(19,32,52)$. Primary sporidia germinate and give rise to secondary sporidia, which germinate and penetrate the wheat floret through stomata (30). Environmental conditions required for sporidial multiplication $(18,65,67)$ and the infection process $(13,20,61)$ have been well documented under controlled conditions. However, specifics of natural disease development in the field are not well documented, and little is known about inoculum densitydisease incidence relationships.

Wheat plants are susceptible to infection from early boot stage to anthesis, but several reports indicate that infection is most successful while the head is still in the boot $(1,35,55,71)$. However, most of these reports are based on hypodermic injection of inoculum into the boot, and results may not be representative of natural infection. As the pathogen infects the immature wheat seed, hyphae infect the pericarp and form a compact layer of mycelium that gives rise to teliospores (15). Growth of the mycelium inside the pericarp eventually ruptures the connection between the pericarp and surrounding vascular bundles, and as a result, the seed atrophies to varying degrees. Partial bunting is common, but in the most extreme cases, the entire seed becomes shriveled and the embryo dies $(15,26,30,54)$ (Fig. 2). In most cases, only a few kernels in each spike become infected (55). There is a significant difference in susceptibility among wheat cultivars, and some are highly susceptible, resulting in a greater percentage of infected kernels per spike. There also have been reports that individual isolates of $T$. indica are more aggressive than others. However, variability among isolates has not been adequate to justify designation of races $(6,10,17,48)$.

Unfortunately, the worldwide concern about Karnal bunt as an important plant pathogen is largely unjustified in terms of the actual damage it causes to wheat yield and quality. When wheat is infected by $T$. indica, diseased seed may have reduced viability and vigor $(4,62,71)$, and flour from grain with over $3 \%$ bunted kernels imparts an off color and unpleasant odor $(58,59)$. However, there are no toxicological issues of concern (7), and the incidence of disease in most fields is typically so low (usually $<0.1 \%$ in the United States) that impact on yield and quality is nonexistent (63). Quality issues can be dealt with by the method of grain processing, and bunted grain can be diluted with clean grain to a point that any negative impact is completely eliminated. Nevertheless, as long as major wheat importing countries maintain restrictive import quarantine laws, the disease will continue to be an economic issue for countries trying to export grain from $\mathrm{Kb}$-infested regions (12). While U.S. regulatory agencies attempt to deregulate the disease, it is only prudent for researchers and others involved in the U.S. wheat industry to be proactive and develop an integrated disease management strategy for 


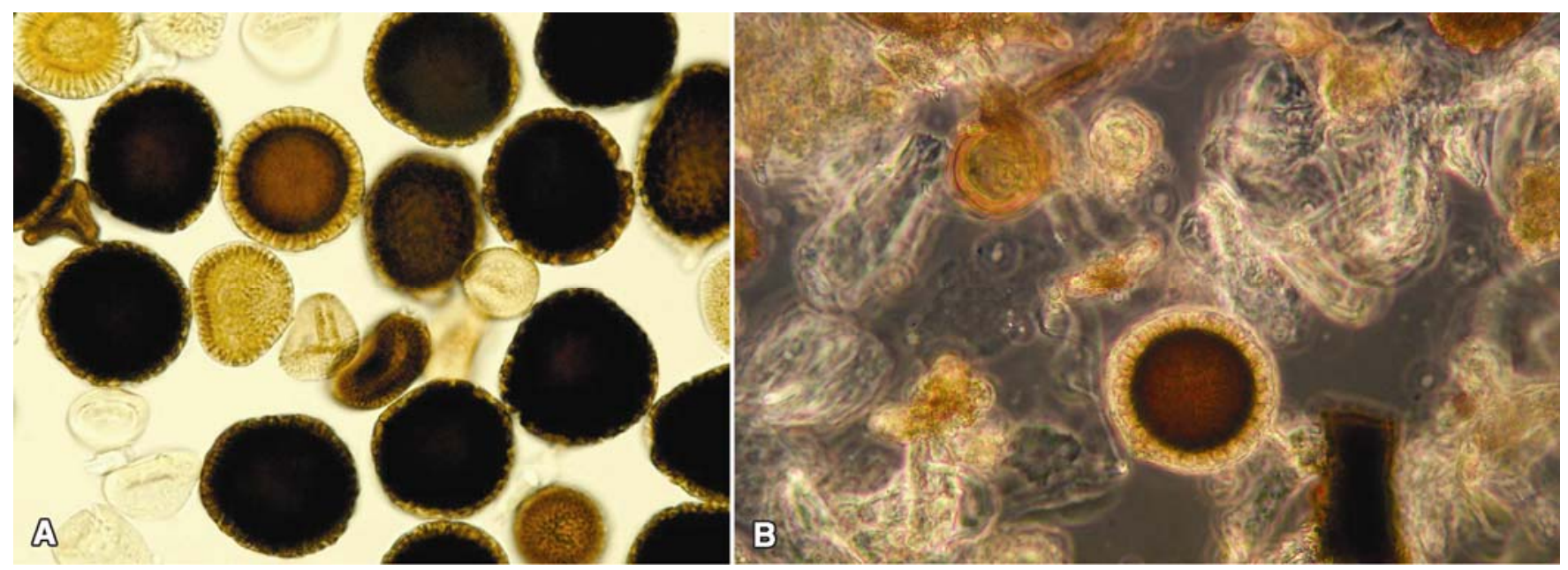

Fig. 1. Teliospores of Tilletia indica. A, Spores scraped from a bunted kernel. (Photo courtesy Blair Goates, USDA-ARS) B, Teliospore recovered from an infested field soil.

$\mathrm{Kb}$ that will help those currently struggling with the disease and those who may be in the future.

\section{Distribution and Spread}

$\mathrm{Kb}$ was first identified in the Karnal district of Northern India in 1931 (62). The disease was soon identified in numerous other regions throughout northern and central India and is now common in several other Asian and Mideastern countries (Fig. 3). The pathogen was not identified outside of Asia until 1972, when it was reported from the state of Sonora in northern Mexico $(25,56)$. At that time, the disease was restricted to the Yaqui and Mayo valleys in Sonora and was found in only trace amounts in farmers' fields. However, in the early 1980s, disease surveys in these valleys found $\mathrm{Kb}$ on $64 \%$ of the farms.

In October 1983, Kb was intercepted, as bunted kernels, at the Calexico, CA, Port of Entry in Mexican boxcars laden with 50-gallon drums of honey from the Yucatan. Subsequently, Mexican boxcars were found frequently contaminated with wheat, and viable teliospores of $T$. indica were found in dust and debris in 9 of 20 randomly selected boxcars. It was concluded that Mexican boxcars destined for the United States and Canada were a potential pathway for the artificial movement of $\mathrm{Kb}$ into the United States $(14,41)$. These interceptions resulted in cooperative $\mathrm{Kb}$ field surveys by USDA and the California Department of Agriculture in the Imperial Valley of California from 1983 to 1988. All surveys failed to find $\mathrm{Kb}$ (T. Boratynski, personal communication).

On 8 March 1996, the first report of Kb in the United States was confirmed on durum wheat in Arizona, and a few weeks later it was confirmed on bread wheat in California. Reference samples of wheat, maintained by the Arizona Department of Agriculture, were tested for $\mathrm{Kb}$, and teliospores of $T$. indica were found in grain

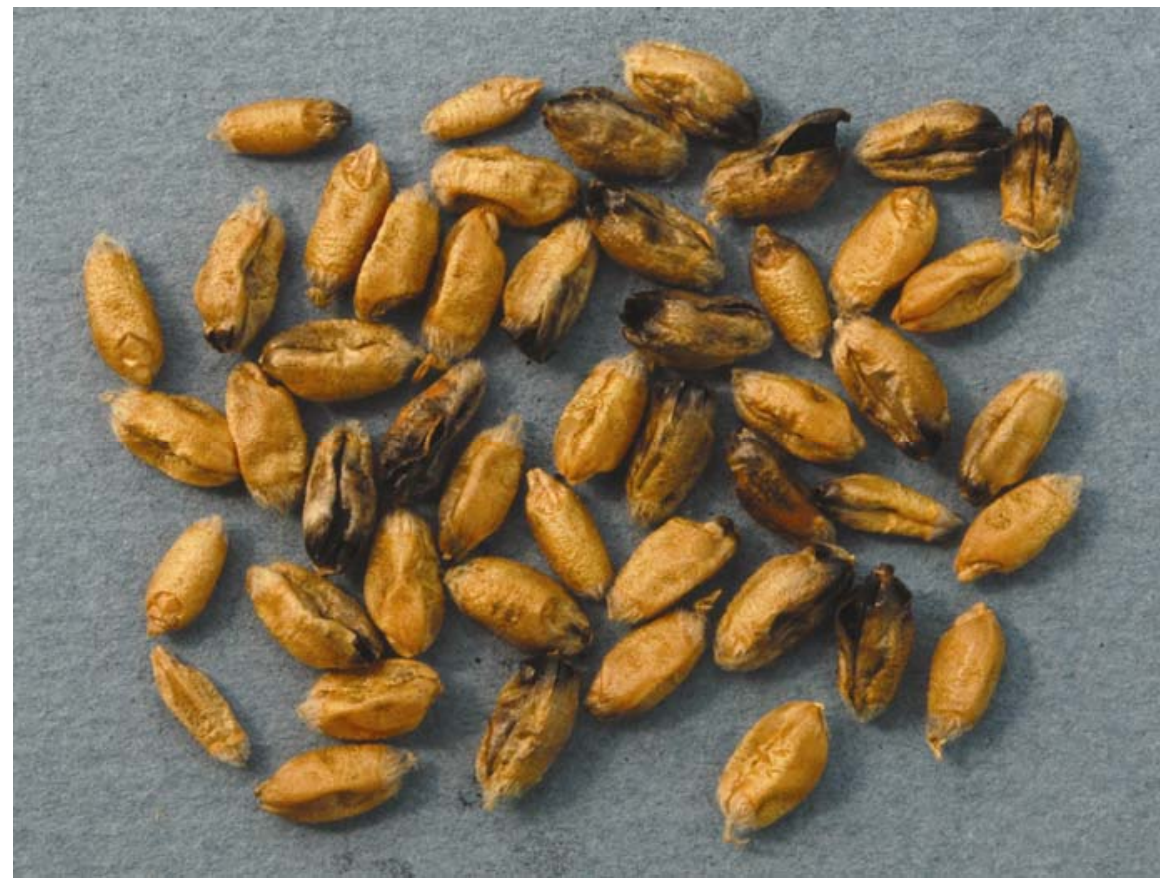

Fig. 2. Bunted kernels infected by Tilletia indica are typically shriveled and frequently exhibit only partial bunting. (Photo courtesy Blair Goates, USDA-ARS)

harvested in 1993, indicating that the disease had been in Arizona in 1992. It was soon discovered that infested seed also had been shipped to, and planted in, New Mexico and Texas (72). Fields that had been planted with infested seed in New Mexico and Texas were destroyed and subsequently monitored for several years, but $\mathrm{Kb}$ was never found. However, in September $1997, \mathrm{~Kb}$ was found in a National Survey grain sample from San Saba County in central Texas. In Arizona, California, and Texas, disease incidence was localized and restricted to relatively small geographic areas. $\mathrm{Kb}$ remained restricted to previously infested areas and was observed only at very low levels until 2001, when a grain elevator operator in Young County in north central Texas, approximately $200 \mathrm{~km}$ north of the quarantined fields in San Saba County, detected bunted kernels. The source of primary inoculum for the new infestation was undetermined, but the discontinuous distribution suggested a human role in the spread from previously infested regions. Subsequent testing of grain samples by APHIS, in and around Young County, resulted in the detection of $T$. indica in the adjacent counties of Archer, Throckmorton, and Baylor. To date, T. indica has not been detected in this area beyond these four counties (Fig. 4, Table 1), but because the Texas High Plains marks the southern boundary of the Great Plains Wheat Production region, the largest, most intensive wheat growing area in the United States, the disease has gained a disproportionate amount of attention. 


\section{Regulatory Responses}

When a disease survey in the early 1980s revealed that $\mathrm{Kb}$ was widespread in the Yaqui and Mayo valleys in Sonora, Mexico, the Mexican government imposed restrictions on movement of seed within the country in hopes of containing the disease (56). In response to Mexico's restrictions on seed movement, plus the fact that $\mathrm{Kb}$ was found in U.S. Crop Quality Council and CIMMYT research plots, the United States imposed a zero tolerance quarantine on the importation of all wheat seed and grain from Mexico $(5,51,71)$. Although only four countries had quarantine restrictions on $\mathrm{Kb}$ before 1982, the number soon increased to 22 following the U.S. action (5). At the time, this had minimal consequence for U.S. producers, and since $\mathrm{Kb}$ had not yet been discovered in the United States, the potential ramifications of the action were scarcely considered.

Domestic response. When $\mathrm{Kb}$ was found in wheat fields in the United States, the consequences of the zero tolerance quarantine became all too apparent. Within 2 weeks of first detecting the disease in Arizona, a "Declaration of Extraordinary Emergency", which provided USDA funding to identify, control, and eradicate the disease, was declared by the Secretary of Agriculture. By the end of April 1996, the USDA had implemented quarantine measures in the entire state of Arizona and in four counties in California, in addition to four counties in New Mexico and two counties in Texas, due to planting infested seed. Specific quarantine measures included a restriction on interstate movement of grain, milling products, and by-prod- ucts, and grain harvesting and shipping equipment (5). Criteria were established to define levels of risk: fields that tested positive for $\mathrm{Kb}$ were termed restricted, and those that were only associated with contaminated seed or equipment were called surveillance or regulated areas. Fields within a 3-mile radius of a restricted field also were included in the regulated area. At the time, detection of a single teliospore of $T$. indica was enough to quarantine a field, but because of the morphological similarities between $T$. indica and $T$. walkeri (16,37), USDA-APHIS established a bunted kernel standard in 1997 for declaring a field $\mathrm{Kb}$ positive. Once a field tested positive, there was no mechanism for that field to ever come out of quarantine. All subsequent $\mathrm{Kb}$-susceptible host crops produced in the field, as well as those in the 3mile regulated area surrounding the restricted field, would be tested for $\mathrm{Kb}$, and severe restrictions were placed on use of the crop, even if it tested negative. The initial idea at this time was that by imposing severe quarantine measures on the movement and processing of wheat from infested areas, the disease could be contained and possibly eradicated.

Ultimately, the success of the imposed quarantine measures, which were instigated to stop the spread of $\mathrm{Kb}$, was impossible to verify. $\mathrm{Kb}$ was later found outside the original quarantined areas, but there was no indication that the pathogen actually spread from previously infested fields. It is possible that each new $\mathrm{Kb}$-positive field resulted from an independent introduction of the pathogen, totally unrelated to previously infested areas. Regardless of the mechanism by which the incidence of

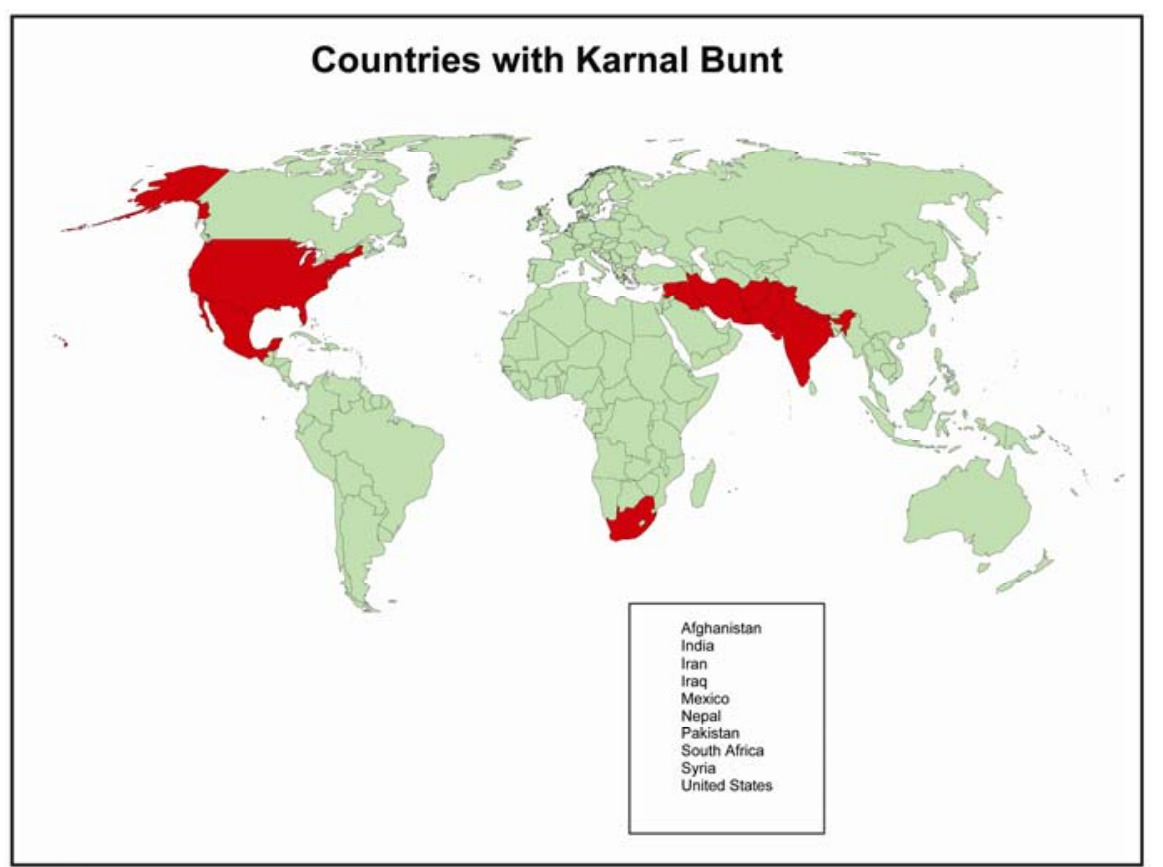

Fig. 3. Countries in which Karnal bunt has been reported as of 2004. Distribution of infested regions within each country is not shown. (Figure courtesy APHIS-PPQ)
$\mathrm{Kb}$ increased in the United States, additional countries imposed trade restrictions on $\mathrm{Kb}$. A detailed chronology of actions taken following introduction of $\mathrm{Kb}$ into the United States, and other information relating to the disease, is provided on the USDA-APHIS-PPQ website.

International response. One of the immediate threats from the initial discovery of $\mathrm{Kb}$ in 1996 was to U.S. export markets. The United States is the world's leading wheat exporter, with exports in 1996 of over 33 million metric tons, accounting for one-third of world wheat exports. At that time, there were 37 countries that listed $\mathrm{Kb}$ as a quarantine pest. These 37 countries accounted for nearly half of U.S. wheat exports. From the date of the discovery, APHIS could no longer issue a phytosanitary export certificate for U.S. exports to these countries on the basis of national freedom from $\mathrm{Kb}$.

Immediately, the USDA Foreign Agricultural Service (USDA-FAS) and APHIS contacted importing countries' plant health authorities to negotiate alternative certification requirements. Based on previous $\mathrm{Kb}$ surveys and the fact that movement of U.S. wheat from $\mathrm{Kb}$-regulated areas was being controlled and kept out of U.S. export channels, APHIS was able to provide, and the majority of the 37 countries accepted, the following additional declaration (A.D.) on the APHIS export certificate: "The wheat in this shipment originated in areas of the United States where Tilletia indica (Karnal bunt) is not known to occur." However, several countries did not immediately approve that language, and negotiations on the language had to be pursued. In addition, 11 countries that had never had a $\mathrm{Kb}$ requirement suddenly asked that the United States now provide the A.D. Since the new certification was relatively easy to provide and time was critical in restoring U.S. exports, there was little need or time to challenge the scientific justifications underpinning importing countries' request for the A.D. Within a few weeks, export certification issues were resolved for most countries requiring an A.D., accounting for approximately $98 \%$ of affected U.S. exports. For several countries (e.g., Chile, Italy, and South Africa), certification issues lingered much longer but were eventually resolved (Fig. 5).

The domestic actions taken under the $\mathrm{Kb}$ program, while considered extreme by many, were all part of the effort to make the additional declaration possible. These actions, which included testing grain for presence of the pathogen, and restricting movement of grain, seeds, and equipment, gave trading partners confidence that the United States was doing everything possible to ensure a disease-free product. The ability to continue to provide the additional declaration was also heavily dependent on the United States' ability to conduct a national survey for $\mathrm{Kb}$. 
National survey. To confirm that $\mathrm{Kb}$ was a problem only in localized areas and not widespread in the U.S. crop, the National Karnal Bunt Survey was initiated in 1996. The actual function of the survey is to provide U.S. certifying officials the data to issue phytosanitary certificates required by countries which import U.S. wheat.
Approximately 650 counties in 39 states participate in the National Survey each year, with sampling ending by the middle of September. Wheat, durum wheat, and triticale are included in the survey. Survey samples are taken from counties where susceptible host crops are produced, and the number of samples is based on the average previous 5-year production of each host for that county (e.g., 1999 to 2003 for the 2004 harvest year). One 4-pound sample is collected for each 1,000,000 bushels of production from producing counties not sampled the previous year and from areas where $\mathrm{Kb}$ has not been detected.

When the National Survey was initiated

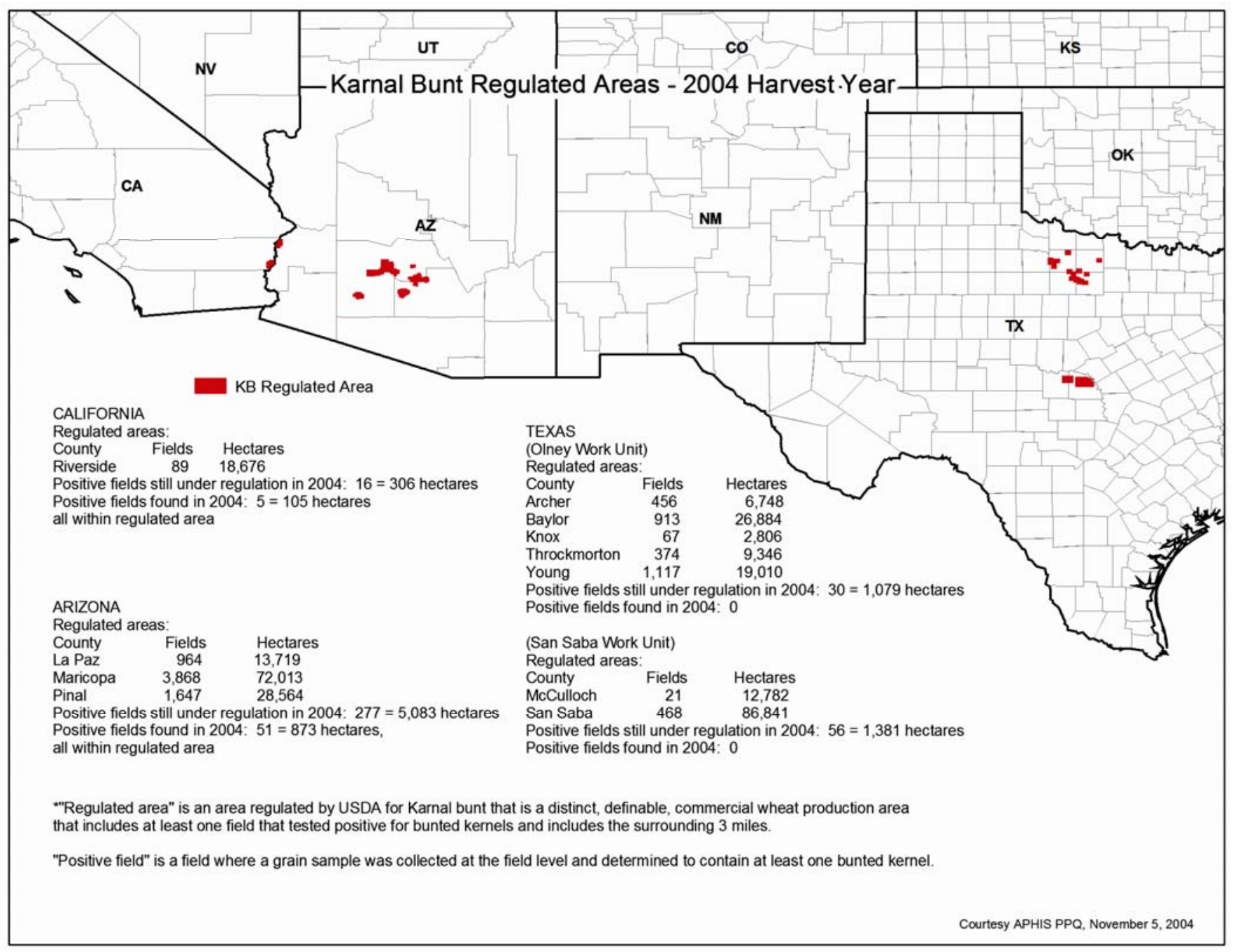

Fig. 4. Regions in the United States regulated for Karnal bunt by USDA-APHIS-PPQ. (Figure courtesy APHIS-PPQ)

Table 1. Area and number of durum and winter wheat fields designated Karnal bunt $(\mathrm{Kb})$ positive, and number of fields tested in Arizona, California, and Texas, by year

\begin{tabular}{|c|c|c|c|c|c|c|c|c|c|}
\hline \multirow[b]{3}{*}{ Year } & \multicolumn{3}{|c|}{ Arizona } & \multicolumn{3}{|c|}{ California } & \multicolumn{3}{|c|}{ Texas } \\
\hline & \multicolumn{2}{|c|}{ Designated positive } & \multirow{2}{*}{$\begin{array}{l}\text { Total fields } \\
\text { tested }\end{array}$} & \multicolumn{2}{|c|}{ Designated positive } & \multirow{2}{*}{$\begin{array}{l}\text { Total fields } \\
\text { tested }\end{array}$} & \multicolumn{2}{|c|}{ Designated positive } & \multirow{2}{*}{$\begin{array}{c}\text { Total fields } \\
\text { tested }\end{array}$} \\
\hline & Ha & \# Fields & & $\mathrm{Ha}$ & \# Fields & & Ha & \# Fields & \\
\hline 1996 & 365 & 18 & $4,430^{\mathrm{a}}$ & 0 & 0 & $854^{\mathrm{b}}$ & $\mathrm{n} / \mathrm{a}$ & $\mathrm{n} / \mathrm{a}$ & $\mathrm{n} / \mathrm{a}$ \\
\hline 1997 & 134 & 4 & 1,212 & 0 & 0 & 141 & 425 & 17 & 18 \\
\hline 1998 & 1,422 & 75 & 1,144 & 64 & 4 & 273 & 0 & 0 & 206 \\
\hline 1999 & 0 & 0 & 825 & 0 & 0 & 71 & 0 & 0 & 173 \\
\hline 2000 & 190 & 14 & 295 & 0 & 0 & 163 & 0 & 0 & 63 \\
\hline 2001 & 1,530 & 92 & 317 & 57 & 3 & 93 & 2,147 & 83 & 295 \\
\hline 2002 & 190 & 12 & 248 & 0 & 0 & 145 & 270 & 4 & 902 \\
\hline 2003 & 454 & 26 & 549 & 126 & 5 & 134 & 0 & 0 & 691 \\
\hline 2004 & 847 & 51 & 317 & 105 & 5 & 89 & 0 & 0 & 818 \\
\hline
\end{tabular}

a This value represents every wheat field planted that season, as all were tested in 1996 due to the initial discovery of Kb within the United States. Later values only represent fields tested in $\mathrm{Kb}$ regulated areas.

b Complete data for 1996 were not available; however, a minimum of 854 fields were tested due to the initial discovery of $\mathrm{Kb}$. 
in 1996, a massive number of samples were required to confirm the limited distribution of $T$. indica in the United States. For example, over 15,000 grain samples were analyzed for the presence of teliospores in that year alone. Such an undertaking required an efficient detection method that was sensitive enough for the "zero-tolerance" status of the regulations at that time. In response, Peterson et al. (46) developed a rapid method using sizeselective sieves in which a single teliospore could be detected at a frequency of $40 \%$ in artificially infested grain samples. This method still relied upon manual visual microscopic analysis of every sample. Linder et al. (38) developed a computerassisted, digital imaging microscopy system that automatically scanned samples and identified objects of similar size, shape, and color intensity (grayscale) to $T$. indica teliospores. Such a system was used by the Kansas Department of Agriculture for the National $\mathrm{Kb}$ Survey until recently (T. Sim, personal communication). The system has now been upgraded to include color-based assessment of suspect objects, increasing effectiveness.

During the first year of the National Survey, a field would be quarantined at the discovery of a single teliospore of $T$. indica, but in 1997, USDA-APHIS adopted the bunted kernel standard. Initially, this entailed screening the entire $1.8-\mathrm{kg}$ grain sample for bunted kernels by visual assessment of each individual kernel, either on a plastic tray or in a vibrating grain inspection machine (49). Since samples typically consist of several thousand kernels, analysis was extremely tedious. Beginning in
2002, a high-speed optical sorter was used that selectively removed, based on seed discoloration, suspected bunted kernels from the sample (21). This technology substantially reduced the amount of material to be examined manually and is now used for all wheat samples in the North Texas Kb-regulated counties and many of the National Kb Survey samples (50).

\section{Research Response to Initial Introduction of $\mathbf{K b}$}

When $\mathrm{Kb}$ was confirmed in the United States, the first research activities were conducted primarily by scientists from USDA-ARS and APHIS. The initial focus was to develop techniques to assist in program management, develop technologies that would mitigate the effects of regulatory actions on producers, and obtain epidemiological information on the pathogen to facilitate development of disease management strategies. Some of the earliest projects by APHIS were conducted in cooperation with the Arizona Department of Agriculture and focused on evaluation of chemical and physical treatments to devitalize teliospores of $T$. indica. The desired result was a treatment that would kill teliospores without negatively impacting the milling quality of grain. Methyl bromide, a fumigant commonly used in quarantine treatments, was not effective in devitalizing teliospores, even at concentrations as high as $6.8 \mathrm{~kg} / 28.3 \mathrm{~m}^{3}(66)$. Various concentrations of propionic acid, a seed treatment for stored grain, and ozone also were evaluated. Surface teliospores were easily killed by propionic acid, but teliospores within the fungal sorus were

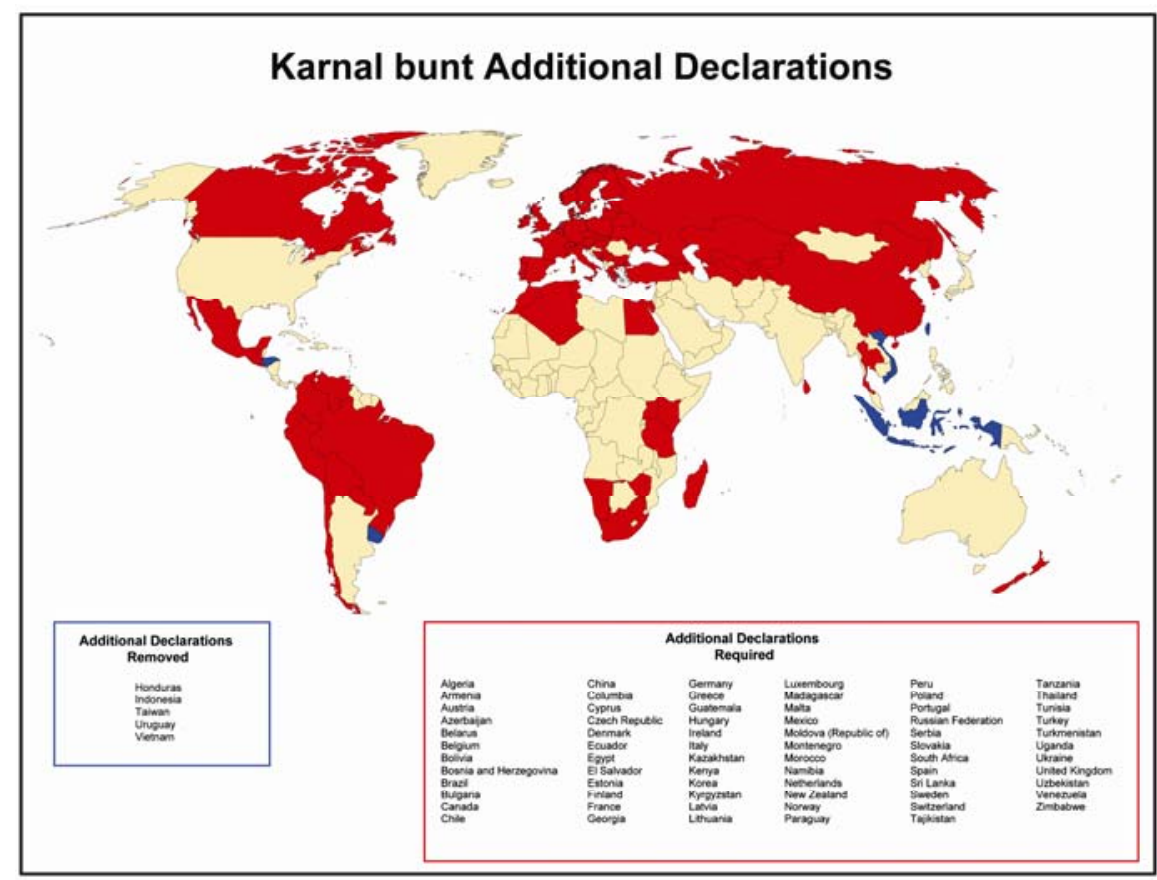

Fig. 5. Before importing U.S. wheat, countries in red require an Additional Declaration for Karnal bunt, while those in blue have recently removed import restrictions. (Figure courtesy APHIS-PPQ) unaffected. Ozone at 19,000 ppm at -61 $\mathrm{kPa}$ pressure for $20 \mathrm{~h}$ also failed to devitalize teliospores of $T$. indica, although the treatment seemed to eliminate the odor of trimethylamine (T. Boratynski and R. E. Ykema, personal communication). Several fungicides were evaluated as seed treatments, but none was efficacious (64).

Heat treatment experiments were conducted on grain destined for animal feed and milling. Steam-flaking is commonly used to treat infested grain for cattle feed, and heating infested grain at $121^{\circ} \mathrm{C}$ for 30 min resulted in $100 \%$ kill of teliospores. Steam flaked grain must be fed immediately, creating logistical problems for large cattle feeding operations. Producers in Texas expressed interest in development of a dry heat treatment that would enable them to store grain after treatment. Lab studies were carried out in a hot air convection oven to determine time and temperature necessary to kill teliospores of $T$. indica. It was determined that $145^{\circ} \mathrm{C}$ for $20 \mathrm{~min}$ or $155^{\circ} \mathrm{C}$ for $10 \mathrm{~min}$ resulted in $100 \%$ mortality (T. Boratynski and R. E. Ykema, unpublished data). A large commercial dryer also was tested and found to be effective in achieving these temperatures.

Teliospore survival and distribution in soil. The earliest studies on the ecology and epidemiology of $\mathrm{Kb}$ in the United States focused on teliospore survival and distribution in soil, because it was recognized that teliospores were the over-wintering stage of the pathogen and served as the primary source of inoculum. Teliospore survival in soil had been studied previously outside of the United States $(29,52)$, but information on survival in U.S. soils was absent. Researchers proposed that understanding the survival of teliospores in various regions and soil types within the United States would offer information that would be useful in determining the potential for pathogen establishment and survival in areas outside of regulated regions. Studies were conducted in Parker and Litchfield Park, AZ, from 1996 to 1998 (57). The Parker field tested positive for $\mathrm{Kb}$ in 1996 and was planted to alfalfa until 1999. The Litchfield Park field also tested positive in 1996 and subsequently was planted to multiple crops. Teliospore populations over time dropped rapidly in the Litchfield Park field but remained relatively constant in the Parker field. The Parker field was replanted to wheat in 1999 and again tested positive for Kb.

In later studies, researchers examined teliospore recovery from soil and viability over time in soil. Babadoost et al. (3) noted that averaged across multiple soil sources from Montana and Washington, the number of teliospores recovered decreased almost fivefold after 8 months and then remained fairly stable until 32 months (3). Bonde et al. $(8,9)$ noted a similar rate of decrease in teliospore recovery and percent 
germination and found significant differences in survival when teliospores were incubated in soils from different regions of the United States under laboratory conditions. In these studies, teliospore recovery and germination were impacted by soil source. However, the specific soil physical and/or chemical factor(s) responsible for this phenomenon was not determined $(3,8)$. It was concluded that in most soils under field conditions, the majority of teliospores rapidly lose viability, especially under irrigated conditions (9), with only a small percentage capable of long-term survival.

The reason the majority of teliospores rapidly lose viability in soil under natural field conditions is currently not understood, but may be a function of soil microbial and/or chemical activity. However, teliospores at, or near, the soil surface are very sensitive to environmental conditions, and periods of high soil moisture and cool temperature $\left(15\right.$ to $\left.20^{\circ} \mathrm{C}\right)$ can induce germination and production of primary sporidia $(22,53,65)$. If conducive conditions are present in the absence of a susceptible host, teliospores may undergo "suicidal" germination and the teliospore population will decline. In contrast, if suboptimal conditions for teliospore germination are present for most of the growing season, teliospores will likely survive longer, with potential to become an inoculum source when the next susceptible crop is planted or when the crop develops a full canopy and a more conducive microclimate for germination and infection is present. Because the complex life cycle of $T$. indica is sensitive to environmental conditions at more points than several other Tilletia species $(33,62)$, this fungus is less likely to become established in areas with less than optimal climatic conditions. Furthermore, because teliospore densities are very low in most infested fields (40), it is possible that a "disproportionate reduction in reproductive success at low population densities", i.e., the Allee effect, will result in reduced disease incidence and increase the probability of pathogen extinction (28). These facts support the recent modification in the federal regulations that $\mathrm{Kb}$-positive fields may be removed from regulation following five seasons of cultivation in the absence of a susceptible crop, or after five seasons with a host crop that tests negative for $\mathrm{Kb}$.

\section{Kb in 2001}

In May 2001, USDA confirmed that wheat in an elevator in Young County, TX, tested positive for Karnal bunt. Unfortunately, over $90 \%$ of the 2001 wheat harvest in that part of the state had been completed, custom harvesters had moved throughout the area, and grain from several counties had been mixed. Subsequent testing of grain samples by APHIS, in and around Young County, detected T. indica in the adjacent Texas counties of Archer, Throckmorton, and Baylor. APHIS added these four counties to the regulated area, halted grain movement in the four counties, and began traceback surveys in an effort to prevent further disease spread. Over 162,000 ha in these four counties of the Texas Rolling Plains were placed under quarantine restrictions, along with 98,000 metric tonnes of grain that were either bunted or co-mingled with bunted grain in the elevator. In 2002, because of the proximity of a Kb-positive field to the county line, the regulated area was further expanded into adjacent Knox County, but no $\mathrm{Kb}$-positive fields have been identified in that county. The total estimated economic impact of $\mathrm{Kb}$ on these counties during 2001 and 2002 exceeded \$25 million (all due to the quarantine status of the pathogen), and the regulated status of the disease continues to cause hardship and lost revenue for producers and wheat-related businesses (Stan Bevers, personal communication).

The 2001 detection of $\mathrm{Kb}$ in North Texas was the first time since 1997 that the disease was detected outside of a previously regulated area in Texas. More importantly, it was the first time $\mathrm{Kb}$ was detected near a primary wheat producing region of the United States. However, from an international trade perspective, because APHIS acted immediately to regulate the new areas where $\mathrm{Kb}$ was detected and prohibited movement of wheat from the area, there was no need to change the phytosanitary certificate, since the addition declaration was still valid. From the trade perspective, the 2001 outbreak was most remarkable for the lack of concern expressed by U.S. trading partners. Unlike in 1996, the USDA in 2001 received formal inquiries about the new $\mathrm{Kb}$ detections only from our North American neighbors, Mexico and Canada. Some brief disruptions in U.S. wheat exports to Mexico occurred, but these were resolved and soon trade was normalized. Canada took no new action against U.S. exports. The fact that there was little or no apparent concern expressed by wheat importing countries when the new $\mathrm{Kb}$ outbreak occurred in 2001 indicated that there was a high level of confidence among U.S. trading partners in the ability of the United States to assure the safety and quality of its wheat exports.

\section{Federal Response to $2001 \mathrm{~Kb}$ Outbreak}

In response to the 2001 outbreak of $\mathrm{Kb}$ in north central Texas, USDA-APHIS held public hearings to build an industry consensus behind a strategy that would preserve the U.S. wheat export market while minimizing economic hardship for producers and grain handlers in and surrounding quarantine areas. Participants agreed that the USDA needed to do everything possible to change the classification of $\mathrm{Kb}$ as a quarantine pest while preserving wheat export markets. As an outcome of this approach, APHIS developed a "Karnal Bunt Strategic Plan for Deregulation While Preserving Export Markets" (see the USDA-APHIS website). The APHIS plan calls for complete deregulation of $\mathrm{Kb}$ as a quarantine pest by 2007 while negotiating with foreign trading partners to modify their wheat import requirements.

Strategic plan. In light of evidence that $\mathrm{Kb}$ was a minor disease, the USDA developed a strategic plan in 2001 to reclassify T. indica as a nonquarantine pest and reduce its impact on the nation's producers, handlers, and exporters. The plan addresses coordination, communication, and national, international, and scientific support activities; and USDA has worked collaboratively with other federal agencies, industry, state cooperators, research institutions, and foreign trading partners to accomplish the plan's goals. USDA continues to coordinate national policy issues related to the strategic plan, to host annual $\mathrm{Kb}$ conferences to update industry and other stakeholders regarding the status of the plan, to work with foreign trading partners and international organizations toward relaxing standards for the export of U.S. wheat, to take actions to minimize the impacts of $\mathrm{Kb}$ on U.S. producers and handlers, and to work with the scientific community to identify research and technical needs to meet the USDA goal of deregulation by 2007. A major component of this overall effort is development of a pest risk analysis.

Pest risk analysis. Pest risk analysis is "the process of evaluating biological or other scientific and economic evidence to determine whether a pest should be regulated and the strength of any phytosanitary measures to be taken against it" (International Plant Protection Convention [IPPC], 1997). It is the USDA position that through pest risk analysis and a concerted effort to communicate with foreign countries, all countries should be able to relax unjustified phytosanitary measures against $\mathrm{Kb}$. Sound science and a transparent and rational approach are being used to present the scientific evidence. Under the operating principles of the IPPC, all countries should strive to use the "least restrictive" phytosanitary measures, commensurate with risk (i.e., to prevent unjustified phytosanitary trade barriers).

USDA-APHIS has participated, through the Pest Risk Analysis Panel of the North American Plant Protection Organization, in conducting "An epidemiological approach to assessing the risk of establishment of Karnal bunt, Tilletia indica Mitra, in North America", October 2001. The conclusion of the panel was that $\mathrm{Kb}$ will likely remain "below levels of regulatory concern" throughout most wheat production regions of North America most of the time, with the exception of weather anom- 
alies (45). Further analyses are underway to quantitatively characterize risks with importation of wheat grain. Risk assessment, conducted as a review of historical data in India (44), indicated $\mathrm{Kb}$ is not a major disease in India since it has not spread beyond certain regions, and is only a problem if severely infested grain is replanted as seed in an unmanaged production system. Similar observations have been made in Mexico (25), and a risk analysis from the European Union will be available soon. To date, all analyses indicate that $\mathrm{Kb}$ is a minor disease, and the most significant negative impact has been caused by domestic and foreign regulations.

\section{University and Commodity Response to $2001 \mathrm{~Kb}$ Outbreak}

The conception of an enhanced $\mathrm{Kb}$ research program grew out of discussions at several meetings that followed the detection of $\mathrm{Kb}$ in North Texas in 2001. Plant pathology department heads attending the North Central Division of the American Phytopathological Society in Manhattan, $\mathrm{KS}$, discussed issues relating to $\mathrm{Kb}$ on 20 June 2001 and agreed that immediate action was required. On 2 August, North Central Region experiment station directors approved formation of a rapid response committee (NC503) to coordinate $\mathrm{Kb}$ research and extension programs of land grant universities. On 16 January 2002, NC503 met in Orlando, FL, in conjunction with the National Association of Wheat Growers and the National Wheat Improvement Committee, and all three entities adopted resolutions calling for increased research on $\mathrm{Kb}$. Members of NC503 and representatives from several wheat commodity organizations traveled to Ciudad Obregon, Sonora, and Mexico City (El Baton) 1 to 5 April 2002 and reviewed CIMMYT's Kb research program. They met with several researchers, who gave a tour of CIMMYT's research plots and facilities, and had discussions to identify areas of mutual interest and to determine how researchers from Mexico and the United States could best collaborate.

The NC503 executive steering committee met in Stillwater, OK, on 27 September 2002. Discussions centered on research needs and priorities, and on identification of individuals to serve on a $\mathrm{Kb}$ Advisory Board, a diverse group of stakeholders who represented a broad spectrum of the U.S. wheat industry. On 7 March 2003, the NC503 Advisory Board met in Oklahoma City with the NC503 executive committee. The group quickly reached consensus that researchers and others involved in the U.S. wheat industry must be proactive and develop an integrated disease management strategy that addressed the variability within the wheat-based agricultural production systems found throughout the
Southern Great Plains. It was agreed that the program should be economically sustainable, broad in scope, and address both the needs of farmers and the concerns of other stakeholders in the region. The group identified six research-extension areas that needed to be addressed in order to accomplish the group's goal of reducing economic losses from $\mathrm{Kb}$ and deregulating the pathogen. These areas were pathogen ecology and epidemiology, germ plasm development, alternate crops and management systems, alternate marketing systems, economics, and extension-education programs. Considerable activity had already been initiated in several of these areas, so the majority of new activity focused on pathogen ecology and epidemiology and germ plasm development.

\section{Pathogen Ecology and Epidemiology Research Needs}

The primary goal for the $\mathrm{Kb}$ ecology and epidemiology project is to provide sound, unbiased scientific data to support the pest risk analysis. Specific areas of research have focused on evaluation of teliospore distribution and viability from wheat fields in Texas and development of improved methods for detection and quantification of $T$. indica in soil and infected plant tissues.

Evaluation of teliospore distribution and viability. Information on the teliospore density and spatial distribution in naturally infested field soils is limited. Babadoost and Mathre (2) found an average of 0.4 teliospores per $10 \mathrm{~g}$ of soil from an Arizona durum wheat field, and Maples et al. (40) found that teliospores were present at similar concentrations in wheat fields from both regulated regions of Texas. Teliospores were essentially detected in every wheat field sampled from the Texas Kb-regulated counties, even fields that had never tested positive. The presence of spores in field soils, without the detection of a bunted kernel from any of the wheat crops sampled from such fields, reinforces the evidence that $T$. indica is a nonaggressive, weakly virulent pathogen. Either infection is not occurring in these negative fields or the incidence is below the detection threshold of the survey method. In either case, without a regular replenishing of the teliospore population in the soil, the long-term survival of $T$. indica is questionable (28). Regulations encouraging the planting of $\mathrm{Kb}$-tested, pathogenfree seed in the regulated areas of the United States also will help promote low populations of the pathogen by eliminating re-introduction of teliospores.

Preliminary studies on the spatial distribution of teliospores within a Kb-positive wheat field in North Texas demonstrated that teliospores had an aggregated distribution in the soil (40), similar to results reported by Sawyer et al. (57), where the incidence of infected kernels was highly aggregated but random in a durum crop. However, the relationship between inoculum density and disease incidence has yet to be elucidated. Studies in Arizona that attempted to determine the minimum teliospore threshold required for infection have been unsuccessful to date because of the lack of suitable environmental conditions, even in the presence of a misting system (G. Peterson, personal communication). While teliospores have been found to survive under a variety of environments, the spatial and environmental aspects of $\mathrm{Kb}$ epidemiology are not well defined.

Improved methods for detection and quantification of $\boldsymbol{T}$. indica in soil and in planta. Numerous methods have been developed to detect $T$. indica and differentiate it from other closely related fungi $(11,23,36,39,42,43,68)$, but few if any of these are quantitative. The method currently used by most researchers to extract and quantify $T$. indica teliospores in soil (2) is tedious and prone to error because of the microscopic analysis of each sample and the loss of teliospores during the extraction process $(3,8)$. Recently, Stein et al. (69) initiated the development of a realtime polymerase chain reaction (PCR) protocol to quantify teliospores in field soil, which will be helpful in studies of the ecology and epidemiology of the pathogen. Preliminary results indicated that the method is sensitive enough to detect $T$. indica DNA in $25-\mathrm{g}$ soil samples artificially infested with only 100 teliospores, or approximately 10 to 20 spores following extraction. The method looks particularly promising for studies such as those where large quantities of teliospores $(1,000+)$ were artificially infested into soil samples in order to study teliospore survival $(3,8)$.

A similar method is in development to quantify $T$. indica DNA in planta following artificial inoculation. Such a method would be useful to study plant-microbe interactions and could help expedite germ plasm screening and development. Currently, inoculations of wheat plants in the United States must be conducted in quarantine facilities or Kb-positive fields under strict permit requirements. Such restrictions hinder the ability of researchers to examine the resistance response in wheat to $T$. indica because of the limited number of facilities and space, as wheat plants must be grown to maturity to quantify the incidence and severity of infection. Real-time PCR could potentially expedite this process by detecting differences in resistance well before crop maturity, allowing for a higher throughput. Also, germ plasm screening and development is essentially all outsourced and conducted in areas where vernalization of winter wheat requires artificial vernalization in an incubator, followed by transplanting. Having additional tools that could be used in the development of resistant varieties within 
the United States would assist in the overall research effort.

\section{Germ Plasm Development Research Needs}

The goal of the germ plasm development project is to develop high-yielding, adapted winter wheat germ plasm with good resistance to $\mathrm{Kb}$ for the Southern Great Plains and other major wheat production regions of the United States. Specific projects include evaluation of currently available hard winter wheat cultivars and breeding lines for resistance to $\mathrm{Kb}$, transfer of $\mathrm{Kb}$ resistance genes from spring wheat sources into adapted winter wheat materials through a backcross program, and development of mapping populations to facilitate marker assisted selection techniques for developing Kb-resistant germ plasm.

Evaluation of currently available hard winter wheat cultivars and breeding lines. Although $\mathrm{Kb}$ is a minor disease, resistant cultivars are nevertheless useful to minimize the impact. Fuentes-Dávila (24) attributed cyclical outbreaks of $\mathrm{Kb}$ in northern India to the popularity of highyielding but highly susceptible varieties. Therefore, a recommended management practice is to plant varieties with at least partial resistance. In the case of dwarf bunt, teliospore thresholds have been established in certain export markets, in which grain is rejected or docked only if teliospore number exceeds the threshold. If similar thresholds are established for $\mathrm{Kb}$, resistant cultivars would decrease the probability that pathogen levels would exceed the threshold level. Resistant cultivars could also reduce the probability of establishment or reduce the rate of spread of the pathogen into new areas (28). If highly resistant cultivars were available, it is possible that established pathogen populations would decrease substantially over time (28).

One of the top priorities for researchers in the United States has been to determine the $\mathrm{Kb}$ resistance levels in existing wheat cultivars. This is very difficult to accomplish in the United States due to quarantine regulations to prevent the spread of the pathogen. Accordingly, much of this screening work has taken place through cooperative projects with CIMMYT in Mexico (Fig. 6) and Punjab Agricultural University (PAU) in India. Researchers tested the susceptibility of 140 U.S. spring wheat lines over at least three seasons in Mexico (31). The majority of cultivars were susceptible, but several lines in all market classes had good resistance. Initial studies with U.S. winter wheat cultivars found moderate to high susceptibility (47). Beginning in 2002, researchers at Oklahoma State University and USDA-ARS organized a Winter Wheat Karnal Bunt Screening Nursery from entries received from various U.S. winter wheat breeding programs. This nursery has been screened by cooperators at CIMMYT and PAU for 2 years. Results to date have confirmed that most U.S. winter wheat cultivars are highly susceptible.

Kb backcross program. Given the lack of resistant winter wheat cultivars, the second priority for researchers in the United States has been to make crosses with known resistant lines. Crosses have been made between nominated wheat lines from different market classes and several sources of resistance from CIMMYT and PAU. Most of these sources confer partial resistance (27), but one has been Kb-free over many years under natural infection and artificial inoculation (60). Cooperating breeders are responsible for subsequent crossing and selection for agronomic type.

Mapping populations for marker assisted selection. Eventually, many segregating populations from many breeding programs must be screened for resistance to $\mathrm{Kb}$. Considering the laboriousness of the inoculation procedure, the environmental variability of the screening method, and the quarantine regulations, marker assisted selection would be very beneficial. Therefore, the third priority for U.S. researchers is to develop and validate molecular markers for $\mathrm{Kb}$ resistance. Several genetic mapping populations are being analyzed by a collaboration of PAU, CIMMYT, USDAARS, and Kansas State University. A gene for resistance has been located on chromosome 4B (70), and other genes are being pursued. The new regional USDA-ARS Cereal Genotyping Laboratories could be used for high throughput marker analysis for $\mathrm{Kb}$ resistance.

\section{Current Efforts}

\section{Toward Deregulation}

Beginning in 1997, USDA changed the focus of the $\mathrm{Kb}$ program from eradication to management of risk associated with the disease. Subsequently, it has established specific goals in a strategic plan that is reviewed annually by stakeholders. It is the objective of the USDA strategic plan to deregulate $\mathrm{Kb}$ as a quarantine pest while preserving wheat export markets. Therefore, USDA is revising domestic regulations to reflect the focus on risk management and to reduce negative economic impact of regulations. USDA is also presenting the international community with mounting evidence that the disease is of minor significance, and is concomitantly revising its import regulations to harmonize with its domestic regulations.

Domestic activities: Revisions to $\mathbf{K b}$ regulations. Adoption of the bunted kernel as the infestation standard necessitated several changes in the $\mathrm{Kb}$ regulations. The changes include: (i) clarifying the method for determining $\mathrm{Kb}$ infestation and the circumstances under which a field or area is classified as a regulated area, (ii) adding criteria for the release of fields or areas from regulation, (iii) clarifying the defini- tion of regulated articles and inspection criteria, and (iv) modifying cleaning and disinfection requirements for certain equipment and storage facilities involved in the harvesting, planting, or storage of $\mathrm{Kb}$-positive host crops or seeds. The changes and proposed changes were intended to improve the clarity and effectiveness of the regulations.

USDA now defines a "regulated area" as any one of the following:

- A field planted with seed from a lot found to contain a bunted wheat kernel;

- A distinct definable area that contains at least one field that was found during a survey to contain a bunted wheat kernel; or

- A distinct definable area that contains at least one field that has been determined to be associated with grain at a handling facility containing a bunted kernel of a host crop.

The distinct definable area may include an area where $\mathrm{Kb}$ is not known to exist but where intensive surveys are required because of that area's proximity to the field associated with the bunted kernel at the handling facility. Noninfested acreage may be included within a regulated area as a buffer, and it too must be surveyed; a 3mile-wide buffer zone around fields or areas affected by $\mathrm{Kb}$ is sufficient.

Revised criteria were developed to release fields from regulation. A field known to have produced a $\mathrm{Kb}$-infected crop, as well as any noninfected acreage surrounding the field, will be released from regulation if the following occur:

- The field is no longer being used for crop production; or

- Each year for a period of five consecutive years, the field is subjected to any one of the following management practices (the practice used may vary from year to year):

- Planted with a cultivated nonhost crop;

- Tilled once annually; or

- Planted with a host crop that tests negative through the absence of bunted kernels.

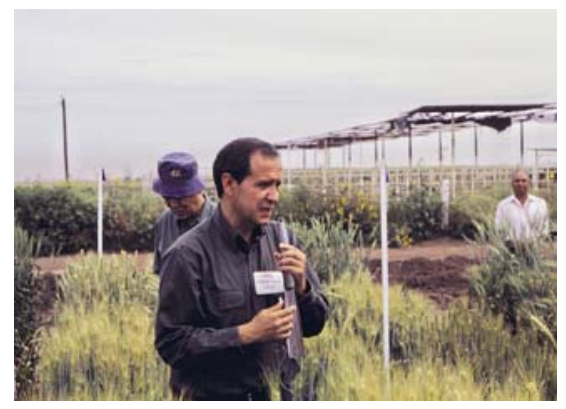

Fig. 6. Dr. Fuentes-Davila giving a tour of a Karnal bunt screening nursery at CIMMYT. Researchers at CIMMYT in Obregon, Mexico, are collaborating with U.S. wheat breeders to develop resistance to Karnal bunt. Some crosses have shown high levels of resistance. 
USDA defines "regulated articles" in order to focus its efforts on pathways by which $\mathrm{Kb}$ may be spread to uninfested areas. Effective 24 March 2004, the list of regulated articles was changed to reflect the bunted kernel standard for infestation, and it includes:

- Conveyances, including trucks, railroad cars, and other containers used to move wheat, durum wheat, or triticale

- Grain elevators, equipment, or structures used for storing and handling wheat, durum wheat, and triticale

- Plants or plant parts, including grain, seed, or straw, or straw of all varieties of wheat ( $T$. aestivum), durum wheat (T. durum), and triticale (T. aestivum $\times$ Secale cereale)

Dropped from the list of regulated articles were the following:

- Milling products or by-products

- Root crops with soil

- Soil from areas where field crops are produced

- Manure from animals that have fed on $\mathrm{Kb}$ host crops

These newly proposed changes would make USDA regulations regarding the importation of wheat and related articles from regions affected with $\mathrm{Kb}$ substantively equivalent to its domestic $\mathrm{Kb}$ regulations. USDA has proposed to list regions and articles that would be regulated for $\mathrm{Kb}$, provide for the recognition of free areas in countries where $\mathrm{Kb}$ is known to be present, describe conditions under which wheat and related articles from regions affected with $\mathrm{Kb}$ could be imported into the United States, and specify cleaning and/or disinfection requirements for imported farm machinery and other equipment used to handle or store Kb-positive seed or host crops. The proposed changes are not final until published in the Federal Register. APHIS also revised its manual for imported nonpropagative material, such as removing spores from the guidelines for inspection and release of wheat as a milled product or by-product. Now, the latter products may be inspected and released if processed to the extent that pests are killed (e.g., bulgur, pelleted wheat, puffed wheat, and roasted grain). If not processed to the extent that pests are killed (the grain is merely cracked, crushed, or ground), but no bunted kernels are found, it is released. If bunted kernels are found, it is refused entry.

International activities. Under the USDA strategic plan for $\mathrm{Kb}$, international activities are focused on two approaches. USDA is engaging countries at the bilateral level to convince them that $\mathrm{Kb}$ is not a pest of quarantine significance and their $\mathrm{Kb}$ import requirements can be removed. At the multilateral level, USDA is continuing its efforts in international plant health organizations to diminish the quarantine status of $\mathrm{Kb}$.

At the bilateral level, the plan calls for a multiyear, incremental strategy. On the trade front, the first step in the plan involves trying to remove $\mathrm{Kb}$ restrictions in countries where they do not appear to be based on scientific reasons or where there is little to no risk. Countries that do not produce wheat would fit that description.

Overall, the strategy calls for placing the 54 countries that require an A.D. into categories according to the perceived level of risk and corresponding estimated ease of removing the restrictions. (As of 1 May 2004, the 54 countries include those of EU consolidation and list the former Soviet Union countries individually.) The 17 countries with no or minimal wheat production were identified as the first group of countries on which to concentrate. Other criteria used in prioritizing the remaining countries include whether the country is an exporter of wheat and its geographic location.

Consistent with the understanding that $\mathrm{Kb}$ should not be a quarantine issue, USDA is taking a low-key approach to removing restrictions internationally. The first step is to informally confirm the status of a country's requirements and then seek confirmation via a broader formal request. Formal follow-up then occurs where necessary.

To date, a formal request to verify or remove $\mathrm{Kb}$ import requirements has been made to 15 countries in the group having little or no wheat production. As of September 2004, the A.D. requirement has so far been removed for four countries (Taiwan, Indonesia, Honduras, and Vietnam) in
Table 2. Number of Karnal bunt (Kb)-positive wheat fields with 1, 2-10, 11-100, or $>100$ bunted kernels for Arizona, California, and Texas since $\mathrm{Kb}$ was first detected in the United States in 1996

\section{Fields within each numerical range of bunted kernels}

\begin{tabular}{lrrrcr}
\cline { 2 - 6 } Location & $\mathbf{1}^{\mathbf{a}}$ & $\mathbf{2 - 1 0}$ & $\mathbf{1 1 - 1 0 0}$ & $\mathbf{> 1 0 0}$ & Total \\
\hline Arizona & 131 & 145 & 43 & 5 & 324 \\
California & 8 & 6 & 2 & 1 & 17 \\
Texas & 46 & 11 & 0 & 1 & 58 \\
Total & 185 & 162 & 45 & 7 & 399 \\
\hline
\end{tabular}

a Number of bunted kernels per field was typically enumerated from a 1.81-kg sample harvested from one location at the edge of a field. Data in this format were not collected for each field at each location every year because in some instances counting stopped after detection of the first bunted kernel. this group, as well as for one country in the wheat producers group (Uruguay). These five countries accounted for over 1.3 million tons of U.S. wheat exports in 2002 to 2003. There are on-going discussions at various stages with the other countries in the initial priority list.

\section{Potential of $\mathrm{Kb}$ as a Significant Disease in the United States}

Since its introduction in 1996, Kb has cost wheat producers in Arizona, California, and Texas millions of dollars. However, as has been clearly demonstrated, losses to $\mathrm{Kb}$ have resulted from the regulatory status of the pathogen rather than adverse effects of the disease on grain yield and quality. It has been documented that $\geq 3 \%$ bunted kernels are necessary to impart an off color or odor to flour from infested grain $(58,59)$. This level of disease has never been found in the United States during testing of crops from regulated areas or during the National Karnal Bunt Survey. When fields are tested, a $1.8-\mathrm{kg}$ sample is collected and the number of bunted kernels per sample determined, but when $\mathrm{Kb}$ was first detected in Arizona, California, and Texas, the total number of bunted kernels in a sample was not always determined because inspectors often quit counting as soon as a sample tested positive. However, from 1997 onward, the total number of bunted kernels per sample has been determined, and in most cases there have been fewer than 10 bunted kernels per sample (Table 2). In fact, over $85 \%$ of the 399 fields that have tested positive for $\mathrm{Kb}$ since 1997 have had 10 or fewer bunted kernels. Since each 1.8-kg sample of wheat will have approximately 45,000 seed or more $(1,000$-kernel seed weights vary greatly and durum wheat is typically heavier than hard red winter wheat), the vast majority of positive fields in the United States have had an infection level of $0.02 \%$ or less. The highest number of bunted kernels from individual field samples has been 478 in Arizona in 2004, 209 in California in 2004, and 224 in Texas in 2001 (approximately $1.0,0.46$, and $0.5 \%$, respectively). The low number of fields that have tested positive for $\mathrm{Kb}$ in the United States since 1996 (Table 1) and the low percentage of bunted kernels from those fields (Table 2) demonstrate conclusively that, from a yield and quality standpoint, $\mathrm{Kb}$ has had no negative impact.

Although incidence and severity of $\mathrm{Kb}$ have been extremely low in the United States, mismanagement can result in higher levels of disease. This was clearly demonstrated during a 2004 fungicide trial that was conducted in an 8-ha durum wheat field in Arizona, which had previously tested positive for $\mathrm{Kb}$ in 2003. At harvest, a total of 384 samples (50 heads each) were collected, and the incidence of bunted kernels in each sample and the distribution of disease across the field were 
determined (Fig. 7). The highest incidence of bunted kernels in a single sample was $11 \%$, the highest ever recorded in the United States. However, the overall field average was still only $2.05 \%$, below the level that would adversely affect baking quality (T. Boratynski, unpublished data). This unusually high level of disease was likely due to a high level of inoculum from the previous $\mathrm{Kb}$-positive wheat crop and environmental conditions that were favorable for disease development during heading. Disease incidence was not well correlated to any fungicide treatment, and distribution across the field was highly aggregated, but it could not be explained by previous cultural practices or physical attributes of the field. This emphasized the fact that numerous aspects of the ecology and epidemiology of this pathogen and disease are still poorly understood.

T. indica has had no negative impact on wheat yield or quality since its introduction into the United States in 1996, and current knowledge of the pathogen and disease indicates no potential significant impact on grain quality or yield in the future. However, as long as T. indica remains a regulated pathogen, it is only prudent for researchers to continue studies that will provide producers information on best management practices and that will provide regulatory agencies the data needed to develop a scientifically based pest risk analysis.

\section{Conclusions}

In hindsight, the establishment of quarantine regulations by the United States for $\mathrm{Kb}$ in 1983 was biologically not justified because $\mathrm{Kb}$ is a minor disease by any measure. Therefore, regulatory agencies should continue their efforts to achieve the ultimate goal of domestic and international deregulation of $T$. indica. The United States has made strides in making domestic regulations more rational, and harmonizing domestic with international regulations. Several grain importing countries have already concluded that $\mathrm{Kb}$ quarantines are not economically justified and have dropped A.D. requirements. It is hoped that other importing countries will come to similar conclusions. In the interim, the United States will continue to develop inexpensive, effective management practices to minimize the economic impact of $\mathrm{Kb}$ on the grain industry.

\section{Acknowledgments}

We thank Terrence Ely, Ruben Guerra, Michael Hennessey, Jerald Levitt, George Nash, Jennifer Pace, Barte Smith, Clifford Smith, and Brian Sterling, and USDA-APHIS-PPQ for providing maps and program data; Ron Ykema, Arizona Department of Agriculture for providing background information and disease incidence data; and Fekede Workneh, TAES, for analyzing data and generating figures. We acknowledge support for portions of this research through Specific Cooperative Agreements between USDA-ARS and Kansas State University, Texas A\&M University, Oklahoma State University, and CIMMYT. Portions of this research were also supported by a research agreement between Punjab Agricultural University and USDAFAS.

\section{Literature Cited}

1. Aujla, S. S., Gill, K. S., Grewal, A. S., and Sharma, I. 1982. New technique of mist spray for Karnal bunt studies. Indian Phytopathol. 35:716-717.

2. Babadoost, M., and Mathre, D. E. 1998. A method for extraction and enumeration of teliospores of Tilletia indica, T. controversa, and T. barclayana in soil. Plant Dis. 82:1357-1361.
3. Babadoost, M., Mathre, D. E., Johnston, R. H., and Bonde, M. R. 2004. Survival of teliospores of Tilletia indica in soil. Plant Dis. 88:56-62.

4. Bansal, R., Singh, D. V., and Joshi, L. M. 1984. Effect of Karnal-bunt pathogen [Neovossia-indica (Mitra) Mundkur] on weight and viability of wheat seed. Indian J. Agric. Sci. 54:663-666.

5. Beattie, B. R., and Biggerstaff, D. R. 1999. Karnal bunt: A wimp of a disease - but an irresistible political opportunity. Choices: The Magazine of Food, Farm and Resources Issues 14:4-8.

6. Beck, R. J., Smith, O. P., Tooley, P. W., Peterson, G. L., and Bonde, M. R. 1994. Characterization of double-stranded RNA from Tilletia indica. Mycologia 86:656-659.

7. Bhat, R. V., Rao, B., Roy, D. N., Vijayaraghavan, M., and Tulpule, P. G. 1983. Toxicological evaluation of Karnal bunt wheat. J. Food Safety 5:105-111.

8. Bonde, M. R., Berner, D. K., Nester, S. E. Peterson, G. L., Olsen, M. W., Cunfer, B. M. and Sim, T. 2004. Survival of Tilletia indica teliospores in different soils. Plant Dis. 88:316324.

9. Bonde, M. R., Nester, S. E., Olsen, M. W., and Berner, D. K. 2004. Survival of teliospores of Tilletia indica in Arizona field soils. Plant Dis. 88:804-810.

10. Bonde, M. R., Peterson, G. L., Fuentes-Davila, G., Aujla, S. S., Nanda, G. S., and Phillips, J. G. 1996. Comparison of the virulence of isolates of Tilletia indica, causal agent of Karnal bunt of wheat, from India, Pakistan, and Mexico. Plant Dis. 80:1071-1074.

11. Bonde, M. R., Peterson, G. L., and Matsumoto, T. T. 1989. The use of isozymes to identify teliospores of Tilletia indica. Phytopathology 79:596-599.

12. Bonde, M. R., Peterson, G. L., Schaad, N. W., and Smilanick, J. L. 1997. Karnal bunt of wheat. Plant Dis. 81:1370-1377.

13. Bonde, M. R., and Smilanick, J. L. 1998. Life cycle and environmental requirements of Tilletia indica. Pages 137-148 in: Proc. Bunts and Smuts of Wheat: An International Symposium, Aug. 17-20, NC, USA.

14. Boratynski, T. N., Matsumoto T. T., and

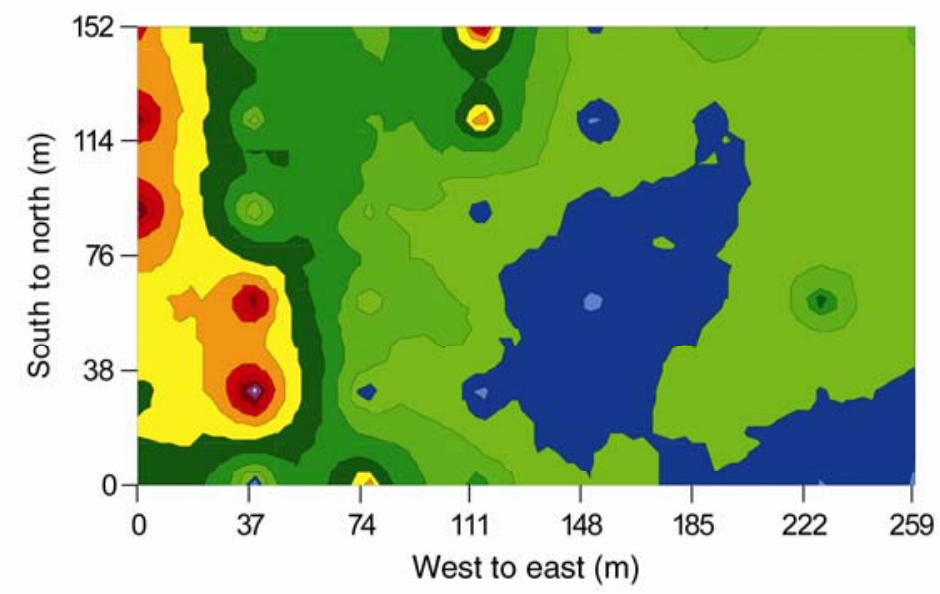

\section{$\%$ Bunted kernels}

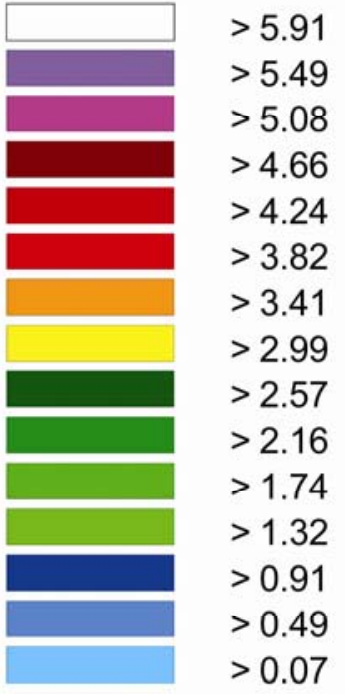


Bonde, M. R. 1985. Interceptions of Tilletia indica at the California-Mexico border in Mexican railroad boxcars. (Abstr.) Phytopathology 75:1339.

15. Cashion, N. L., and Luttrell, E. S. 1988. Hostparasite relationships in Karnal bunt of wheat. Phytopathology 78:75-84.

16. Castlebury, L. A., and Carris, L. M. 1999. Tilletia walkeri, a new species on Lolium multiflorum and L. perenne. Mycologia 91:121-131.

17. Datta, R., Rajebhosale, M. D., Dhaliwal, H. S., Singh, H., Ranjekar, P. K., and Gupta, V. S. 2000. Intraspecific genetic variability analysis of Neovossia indica causing Karnal bunt of wheat using repetitive elements. Theor. Appl. Genet. 100:569-575.

18. Dhaliwal, H. S. 1989. Multiplication of secondary sporidia of Tilletia indica on soil and wheat leaves and spikes and incidence of Karnal bunt. Can. J. Bot. 67:2387-2390.

19. Dhaliwal, H. S., and Singh, D. V. 1988. Up-todate life cycle of Neovossia indica (mitra) mundkur. Curr. Sci. 57:675-677.

20. Dhiman, J. S., Bedi, P. S., and Mavi, H. S. 1984. Relationship among temperature, humidity, and incidence of Karnal bunt of wheat. Indian J. Ecol. 2:134-138.

21. Dowell, F. E., Boratynski, T. N., Ykema, R. E., Dowdy, A. K., and Staten, R. T. 2002. Use of optical sorting to detect wheat kernels infected with Tilletia indica. Plant Dis. 86:1011-1013.

22. Dupler, M., Smilanick, J. L., and Hoffmann, J. A. 1987. Effect of matric and osmotic potential on teliospore germination of Tilletia indica. Phytopathology 77:594-598.

23. Frederick, R. D., Snyder, K. E., Tooley, P. W., Berthier-Schaad, Y., Peterson, G. L., Bonde, M. R., Schaad, N. W., and Knorr, D. A. 2000. Identification and differentiation of Tilletia indica and $T$. walkeri using the polymerase chain reaction. Phytopathology 90:951-960.

24. Fuentes-Davila, G. 1996. Karnal bunt. Pages 26-32 in: Bunt and Smut Diseases of Wheat: Concepts and Methods of Disease Management. R. D. Wilcoxson and E. E. Saari, eds. CIMMYT, Mexico, D.F.

25. Fuentes-Davila, G. 1998. Karnal bunt of wheat. Pages 69-81 in: Proc. Bunts and Smuts of Wheat: An International Symposium. North Carolina. North American Plant Protection Organization, Ottawa, ON.

26. Fuentes-Davila, G., and Duran, R. 1986. Tilletia indica cytology and teliospore formation in vitro and in immature kernels. Can. J. Bot. 64:1712-1719.

27. Fuentes-Davila, G., and Rajaram, S. 1994. Sources of resistance to Tilletia indica in wheat. Crop Prot. 13:20-24.

28. Garrett, K. A., and Bowden, R. L. 2002. An Allee effect reduces the invasive potential of Tilletia indica. Phytopathology 92:1152-1159.

29. Gill, K. S., Sharma, I., and Aujla, S. S. 1993. Karnal bunt and wheat production. 1st ed. Punjab Agricultural University. Ludhiana, Punjab, India.

30. Goates, B. J. 1988. Histology of infection of wheat by Tilletia indica, the Karnal bunt pathogen. Phytopathology 78:1434-1441.

31. Goates, B. J., and Fuentes-Dávila, G. 2003. Reaction of U.S. spring wheat cultivars to Karnal bunt. (Abstr.) Phytopathology 93:S29.

32. Holmes, G. J., Jackson, L. F., and Perring, T. M. 1996. Imperial Valley conditions limit Karnal bunt in wheat. Calif. Agric. 51:29-33.

33. Joshi, L. M., Singh, D. V., Srivastava, K. D., and Wilcoxson, R. D. 1983. Karnal bunt - a minor disease that is now a threat to wheat. Bot. Rev. 49:309-330.

34. Krishna, A., and Singh, R. V. 1983. Longevity of teliospores of Neovossia indica causing Karnal bunt of wheat. Indian J. Mycol. Plant Pathol. 13:97-98

35. Kumar, J., and Nagarajan, S. 1998. Role of flag leaf and spike emergence stage on the in- cidence of Karnal bunt in wheat. Plant Dis. 82:1368-1370.

36. Kutilek, V., Lee, R., and Kitto, G. B. 2001. Development of immunochemical techniques for detecting Karnal bunt in wheat. Food Agric. Immunol. 13:103-114

37. Levy, L., Castlebury, L. A., Carris, L. M., Meyer, R. J., and Pimentel, G. 2001. Internal transcribed spacer sequence-based phylogeny and polymerase chain reaction-restriction fragment length polymorphism differentiation of Tilletia walkeri and T. indica. Phytopathology 91:935-940.

38. Linder, K. D., Baumgart, C. W., Creager, J., Heinen, R., Troupe, T., Meyer, D., Carr, J., and Quint, J. 1998. Automated detection of Karnal bunt teliospores. Pages: 80-87 in: Proc. Machine Vision Applications in Industrial Inspection VI. A. R. Rao and N. Chang, eds. International Society for Optical Engineering, San Jose, CA.

39. Luster, D. G., Bonde, M. R., Peterson, G. L., Hack, M. A., and Schaad, N. W. 1998. Antigenic glycoproteins in the teliospore wall of Tilletia indica. Mycologia 90:180-188.

40. Maples, H. W., Stein, J. M., and Rush, C. M. 2004. Recovery of Tilletia indica teliospores from regulated fields in Texas. (Abstr.) Phytopathology 94:S168.

41. Marshall, D., Work, T. T., and Cavey, J. F. 2003. Invasion pathways of Karnal bunt of wheat into the United States. Plant Dis. 87:999-1003.

42. Matsumoto, T., Mccarty, J., Prescott, M., and Datnoff, L. 1989. Glycerol filtration seed assay. Pages 153-154 in: Laboratory Guide for the Identification of Smut Fungi of Quarantine Significance to California. T. Matsumoto and T. Bell, eds. California Department of Food and Agriculture. Sacramento.

43. McDonald, J. G., Wong, E., and White, G. P. 2000. Differentiation of Tilletia species by repPCR genomic fingerprinting. Plant Dis. 84:1121-1125.

44. Nagarajan, S., Aujla, S. S., Nanda, G. S., Sharma, I., Goel, L. B., Kumar, J., and Singh, D. V. 1997. Karnal bunt (Tilletia indica) of wheat - a review. Rev. Plant Pathol.76:12071214.

45. Pest Risk Analysis Committee. 2001. An epidemiological approach to assessing the risk of establishment of Karnal bunt, Tilletia indica Mitra, in North America. North American Plant Protection Organization, Ottawa, ON.

46. Peterson, G. L., Bonde, M. R., and Phillips, J. G. 2000. Size-selective sieving for detecting teliospores of Tilletia indica in wheat seed samples. Plant Dis. 84:999-1007.

47. Peterson, G. L., and Creager, R. A. 2000. Susceptibility of winter wheat to Karnal bunt. (Abstr.) Phytopathology 90:S60.

48. Pimentel, G., Carris, L. M., Levy, L., and Meyer, R. J. 1998. Genetic variability among isolates of Tilletia barclayana, T. indica and allied species. Mycologia 90:1017-1027.

49. Plant Protection and Quarantine. 2002. Karnal bunt manual. U.S. Department of Agriculture, Frederick, MD

50. Plant Protection and Quarantine. 2004. National Karnal bunt wheat grain survey. U.S. Department of Agriculture, Riverdale, MD

51. Poe, S. 1998. APHIS response to Karnal bunt prior to March 1996. Pages 107-111 in: Proc. Bunts and Smuts of Wheat: An International Symposium. North Carolina. North American Plant Protection Organization, Ottawa, ON.

52. Rattan, G. S., and Aujla, S. S. 1990. Survival of Karnal-bunt (Neovossia indica) teliospores in different types of soil at different depths. Indian J Agric. Sci. 60:616-618.

53. Rattan, G. S., and Aujla, S. S. 1992. Ecology of germination of the teliospore of Karnal bunt pathogen (Neovossia indica). Indian J. Agric. Sci. 62:228-231.

54. Roberson, R. W., and Luttrell, E. S. 1987. Ultrastructure of teliospore ontogeny in Tilletia indica. Mycologia 79:753-763.

55. Royer, M. H., and Rytter, J. 1985. Artificial inoculation of wheat with Tilletia indica from Mexico and India. Plant Dis. 69:317-319.

56. Sansford, C. E. 1998. Karnal bunt (Tilletia indica): An assessment of the significance of the initial detection of Tilletia indica Mitra in the USA in early 1996 and the potential risk to the United Kingdom (and the European Union). Pages 273-302 in: Proc. Bunts and Smuts of Wheat: An International Symposium. North Carolina. North American Plant Protection Organization, Ottawa, ON.

57. Sawyer, A. J., Huettel, R. N., and Meyer, R. J. 1997. Within-field spatial distribution of Tilletia indica (Karnal bunt): Implications for desurveys. (Abstr.) Phytopathology $87:$ S85

58. Sekhon, K. S., Randhawa, S. K., Saxena, A. K., and Gill, K. S. 1981. Effect of washingsteeping on the acceptability of Karnal bunt infected wheat for bread, cookie and chapati making. J. Food Sci. Technol. 18:1-2.

59. Sekhon, K. S., Singh, N., and Singh, R. P. 1992. Studies on the improvement of quality of wheat infected with Karnal bunt. I. Milling, Rheological, and Baking Properties. Cereal Chem. 69:50-54.

60. Sharma, I., Bains, N. S., and Nanda, G. S. 2004. Inheritance of Karnal bunt-free trait in bread wheat. Plant Breed. 123:96-97.

61. Singh, A. 1994. Epidemiology and management of Karnal bunt disease of wheat. University of Agriculture and Technology Res. Bull. No. 127. Pantnagar, U.P., India.

62. Singh, D. V., Joshi, L. M., and Srivastava, K. D. 1983. Karnal bunt. A new threat to wheat in India. Pages 121-135 in: Recent Advances in Plant Pathology. H. K. Festchrift, ed. Prin House, Lucknow, India.

63. Singh, N., Sekhon, K. S., Srivastava, A. K. and Gupta, P. P. 1992. Studies on the improvement of quality of wheat infected with Karnal bunt. II. Nutritional and biological effects. Cereal Chem. 69:55-60.

64. Smilanick, J. L., Hoffmann, J. A., Cashion, N L., and Prescott, J. M. 1987. Evaluation of seed and foliar fungicides for control of Karnal bunt of wheat. Plant Dis. 71:94-96.

65. Smilanick, J. L., Hoffmann, J. A., and Royer, M. H. 1985. Effect of temperature, pH, light, and desiccation on teliospore germination of Tilletia indica. Phytopathology 75:1428-1431.

66. Smilanick, J. L., Hoffmann, J. A., Secrest, L. R., and Wiese, K. 1988. Evaluation of chemical and physical treatments to prevent germination of Tilletia indica teliospores. Plant Dis $72: 46-51$

67. Smilanick, J. L., Prescott, J. M., Hoffmann, J. A., Secrest, L. R., and Weise, K. 1989. Environmental effects on survival and growth of secondary sporidia and teliospores of Tilletia indica. Crop Prot. 8:86-90.

68. Smith, O. P., Peterson, G. L., Beck, R. J., Schaad, N. W., and Bonde, M. R. 1996. Development of a PCR-based method for identification of Tilletia indica, causal agent of Karna bunt of wheat. Phytopathology 86:115-122.

69. Stein, J. M., Maxson-Stein, K. L., and Rush, C. M. 2004. The use of real-time PCR to quantify the number of Tilletia indica teliospores (Abstr.) Phytopathology 94:S169.

70. Sukhwinder-Singh, Brown-Guedira, G. L., Grewal, T. S., Dhaliwal, H. S., Nelson, J. C., Singh, H., and Gill, B. S. 2003. Mapping of resistance gene effective against Karnal bunt pathogen of wheat. Theor. Appl. Genet. 106:287-292.

71. Warham, E. J. 1990. A comparison of inoculation techniques for assessment of germplasm susceptibility to karnal bunt (Tilletia indica) disease of wheat. Ann. Appl. Biol. 116:43-60.

72. Ykema, R. E., Floyd, J. P., Palm, M. E., and Peterson, G. L. 1996. First report of Karnal bunt of wheat in the United States. Plant Dis. 80:1207. 


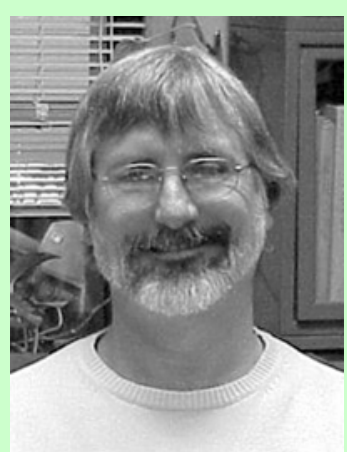

Charles M. Rush

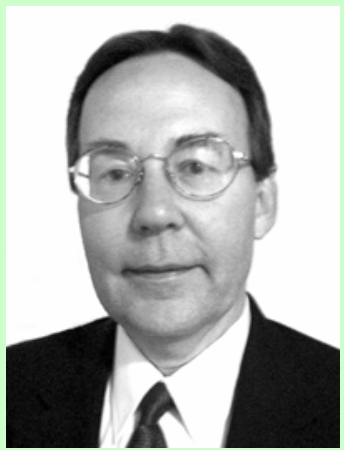

Robert Riemenschneider

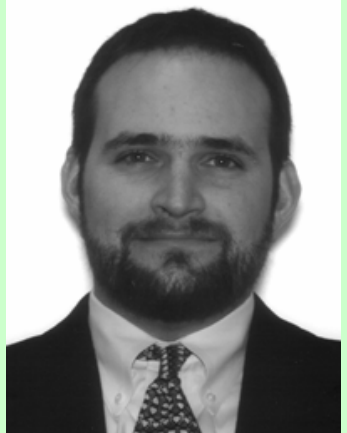

Jeffrey M. Stein

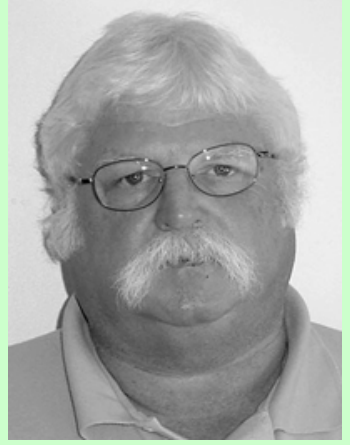

Theodore Boratynski

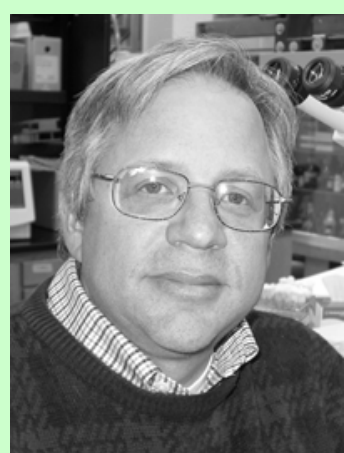

Robert L. Bowden

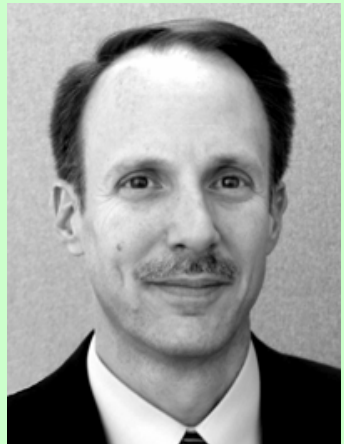

Matthew H. Royer
Dr. Rush was born in Anthony, KS, and grew up in Odessa, TX. He worked his way through college in the oil fields of west Texas and in 1974 received a B.A. degree in literature from the University of Texas Permian Basin. He attended Texas A\&M and under the direction of Dr. Stuart Lyda received a master of agriculture degree in plant protection in 1976 and a Ph.D. in plant pathology in 1981. He worked as a postdoc with the Texas Agricultural Experiment Station in Temple, TX, from 1981 to 1983 and with USDA-ARS in Prosser, WA, from 1983 to 1986. He was hired as an associate professor with TAES in Amarillo in 1986 and was promoted to professor in 1991. Dr. Rush currently leads a diverse research program that includes projects on Karnal bunt, sorghum ergot, rhizomania of sugar beet, Wheat streak mosaic virus, and remote sensing for detection and quantification of plant disease.

Dr. Stein is an assistant professor in the Department of Plant Science at South Dakota State University in Brookings. He received his B.S. degree in botany and plant pathology (1997) and Ph.D. degree in plant pathology (2002) from Michigan State University in East Lansing. He was a postdoctoral research associate at the Texas Agricultural Experiment Station in Bushland from 2002 to 2004, where he conducted research on the survival and QPCR-based quantification of Tilletia indica teliospores in soil under the guidance of Dr. Rush. He joined the faculty at South Dakota State University in 2004 and directs a research program that focuses on fungal diseases of small grains. His current research interests include the epidemiology of Fusarium head blight, common root rot, and tan spot.

Dr. Bowden received his B.S. in botany and plant pathology from Michigan State University (1978), his M.S. in plant pathology from the University of Minnesota (1981), and his Ph.D. in plant pathology from the University of Wisconsin (1989). He worked as an extension specialist in plant pathology at Kansas State University from 1989 to 2002, focusing on disease management in cereals and forage crops. In 2002, he joined the USDA-ARS as research leader of the Plant Science and Entomology Research Unit in Manhattan, KS. His research interests include fungal genetics, fungal population biology, and genetic resistance to diseases of wheat.

Mr. Riemenschneider is the director of the grain and feed division of the Foreign Agricultural Service (FAS), USDA, a position he has held since January 1996. His responsibilities include overseeing FAS's efforts in the area of foreign commodity analysis and market development for grain and feed commodities, and providing the analytical support for those commodities in the operation of USDA's export programs, foreign market promotion activities, and trade policy initiatives. He has been a member of the USDA
Karnal bunt $(\mathrm{Kb})$ Task Force since its inception and is responsible for coordinating USDA efforts with foreign governments aimed at reducing Kb-related restrictions on imports of U.S. wheat. He joined the Foreign Agricultural Service in 1975 and has worked in the trade policy and commodity program areas, as well as doing a tour as U.S. Agricultural Attache at the American Embassy in Paris. He holds B.S. and M.S. degrees in agricultural economics from Rutgers University. He is a native of Bel Air, MD, where he grew up on the family dairy farm.

Mr. Boratynski has a half-time appointment as a research plant pathologist at the Decision Support and Pest Management Systems Laboratory, USDA/APHIS/PPQ CPSHT, in Phoenix, AZ. He received his B.A. in history from the University of San Francisco in 1967 and an M.S. in botany with a specialty in mycology from California State University, Chico, in 1973. Prior to his career with USDA, he served as Smithsonian Institution Peace Corps volunteer in the Department of Plant Pathology, Ministerio de Agricultura y Ganaderia in San Jose, Costa Rica, from 1976 to 1978 . His career with USDA began in Albany, NY, in 1979. He has worked on many PPQ plant pathology program pests including Scleroderris canker, golden nematode, citrus canker in Florida and Mexico, Plum pox virus in Pennsylvania and New York, sudden oak death, soybean rust, and Karnal bunt. His current research involves evaluating chemical and physical treatments to devitalize teliospores of Tilletia indica and the development of a thermal death kinetic model for Karnal bunt.

Dr. Royer received his doctorate in plant pathology from Pennsylvania State University with emphases in quantitative epidemiology and genetics. After graduation, he served as plant pathologist with the USDA Agricultural Research Service (ARS) at Ft. Detrick, MD, where he conducted experiments to assess the risk of foreign plant diseases (e.g., Karnal bunt) to the United States at the Foreign Disease-Weed Science Research Unit. After 6 years with ARS, he accepted a position with the USDA, Animal and Plant Health Inspection Service (APHIS), where he has served for 14 years. During his time with APHIS, he has served in a variety of positions including senior plant pathologist, chief operations officer of the biological assessment and taxonomic support staff, project manager and subsequently interim and associate director, establishing the Center for Plant Health Science and Technology in Raleigh, NC, and Director, Invasive Species and Pest Management, Pest Detection and Management Programs (PDMP). In his current position, he is the senior program advisor, PDMP, providing PPQ policy leadership in high-profile programs such as Karnal bunt, Phytophthora ramorum, Ralstonia solanacearum race 3 biovar 2 , and soybean rust. 